\title{
Can local ecological knowledge provide meaningful information on coastal cetacean diversity? A case study from the northern South
}

\section{China Sea}

Mingli Lin ${ }^{1}$, Luru Xing ${ }^{1}$, Liang Fang ${ }^{1,2}$, Shiang-Lin Huang ${ }^{3}$, Chiou-Ju Yao Samuel T. Turvey ${ }^{5}$, Rodolphe E. Gozlan ${ }^{6}$, Songhai Li ${ }^{1 *}$

1. Sanya Key Laboratory of Marine Mammal and Marine Bioacoustics, Institute of Deep-Sea Science and Engineering, Chinese Academy of Sciences, Sanya, Hainan, China

2. School of Marine Sciences, Sun Yat-Sen University, Zhuhai, Guangdong, China

3. College of Science, Shantou University, Shantou, Guangdong, China

4. Department of Biology, National Museum of Natural Science, Taichung, Taiwan, China

5. Institute of Zoology, Zoological Society of London, Regent's Park, London, UK

6. ISEM, Université de Montpellier, CNRS, IRD, EPHE, Montpellier, France

Running Head: Can local ecological knowledge reveal cetacean diversity?

* Correspondent author: lish@idsse.ac.cn; 28 Luhuitou Road, Sanya, 572000, China. 


\begin{abstract}
Identifying and evaluating potentially suitable tools to assess the status of cetaceans in coastal waters with high levels of anthropogenic threat represents a first step towards effective cetacean conservation management. Local ecological knowledge (LEK) can often provide more extensive information on focal species and biological resources than is available from standard ecological surveys, and is increasingly recognized as an important source of data for conservation research and management, but it has rarely been used as a tool to assess the status of cetaceans. We investigated the efficacy of using LEK from local fishers combined with stranding records to characterise the diversity and distribution of coastal cetaceans in the northern South China Sea, a region with high historical levels of cetacean abundance and diversity but which is experiencing intensifying anthropogenic pressures. Fishers were unable to identify most regionally occurring cetaceans to species level. However, we were able to determine the distributions of eight categories of cetaceans that were observed by fishers, and a previously unknown population of Indo-Pacific humpback dolphin reported from the coastal waters of Hainan that was later confirmed through boat-based surveys. The number of sightings of different cetacean categories reported by fishers has a significant positive linear relationship with independent data on numbers of stranded cetaceans, validating the accuracy of our respondent data and indicating that LEK can provide useful, quantitative information on abundance rankings of different cetacean categories.
\end{abstract}

Keywords: Hainan; Indo-Pacific humpback dolphin; questionnaire survey; South China Sea; traditional ecological knowledge. 


\section{Introduction}

Cetacean populations are increasingly recognised to be showing declines across the globe (Taylor et al., 2007; Schipper et al., 2008). Cetacean declines are often detected through observed contractions in species' geographic ranges, which are associated with regional population extirpation (Channell and Lomolino, 2000; Mace et al., 2008). However, standardised cetacean monitoring data are unavailable for many regions, including some ecologically important coastal areas, due to limited resources (time, funding and manpower) available to conduct quantitative boat-based surveys (Aragones et al., 1997; Richman et al., 2014). This data limitation therefore makes estimation of cetacean status or geographic distribution difficult or impossible for these regions, hindering identification of possible range change through time.

Visual surveying and acoustic monitoring constitute the two main traditional cetacean ecological research methods. Precise data about cetacean species occurrence and group size can be collected through visual observation, and distance sampling and photo-identification can be further used to estimate abundance (Buckland et al., 1993; Fearnbach et al., 2012). Acoustic data can also be collected in the field using hydrophones, and used to determine species occurrence, distribution and even abundance (Mellinger et al., 2007; Li et al., 2010). However, visual and acoustic monitoring are time-consuming and associated with high financial and labour costs (Aragones et al., 1997; Richman et al., 2014), and these disadvantages can limit their use in long-term or large-scale studies. 
Alternative sources of data on coastal cetacean status and diversity may also be available to inform scientific understanding and conservation planning, notably from untrained local marine resource users who utilise the same environments as cetaceans. Local ecological knowledge (LEK) represents experiential knowledge from such resource users that is derived from their lived interactions with the local environment (Inglis 1993; Berkes et al. 2000; Newing, 2011). Over the last 30 years, LEK has increasingly been recognized as a potentially useful tool for addressing diverse questions on ecological and applied conservation issues (Johannes et al., 2000; Olsson and Folke 2001). In particular, LEK is often able to provide useful information about the status of target species and ecological resources (Newing, 2011; Sousa et al., 2013; Ziembicki et al., 2013; Turvey et al., 2014; Marin et al., 2017), and thus represents a potential management tool for marine protected areas and wider marine biodiversity (Gerhardinger et al., 2009; Sanchez-Carnero et al., 2016). Questionnaire surveys to collect LEK from fishers have been suggested as a potentially effective and economical method for assessing cetacean status and diversity across wide geographic areas, especially for rare or elusive species that may otherwise be difficult to study or monitor, and this approach can also provide both historical and recent data with a single collection effort (Turvey et al., 2010). LEK has so far been demonstrated to represent an important tool for studying population declines and extinction patterns in freshwater cetaceans (Turvey et al., 2010, 2012), folk classification of cetaceans by fishers (Souza and Begossi, 2007), fishers' perceptions of dolphin-fisheries 
interactions (Goetz et al., 2014; Gonzalvo et al., 2014), and patterns of bycatch in multiple cetacean species (Lopez et al., 2003; Liu et al., 2016).

However, there is considerable potential for error and bias in the collection, interpretation and quantification of LEK data, which can prevent its straightforward use for providing baselines on cetacean diversity and distribution (Turvey et al., 2014; Caruso et al., 2016). Although extensive data on local cetacean status can often be provided in systems where few or only single species are present (e.g. freshwater systems), or where researchers are primarily interested in LEK associated with specific easily identifiable target species, accurate LEK data on broader patterns of regional cetacean species composition in marine environments may be difficult to obtain if untrained local observers are unable to distinguish effectively between morphologically or ecologically similar species. Using approximated or qualitative data collected during interview surveys to develop quantitative estimates of cetacean abundance or to map species distributions across large marine areas is also a major challenge. It is therefore necessary to evaluate the extent to which the use of interview surveys to collect LEK can provide meaningful information on different aspects of cetacean status in high-diversity marine environments, and whether it is possible to validate the quality of LEK datasets.

The South China Sea (SCS), an area of over 3.5 million $\mathrm{km}^{2}$ that extends from the Strait of Malacca in the southwest to the Strait of Taiwan in the northeast, is a geographic region with high historical levels of cetacean abundance and diversity (Wang, 2011). Data on the regional status of most cetacean species in the SCS is 
restricted to sporadic stranding records (Hao et al., 2011; Wang, 2011), with scientific surveys conducted in coastal waters for only a few species, most notably the IndoPacific humpback dolphin Sousa chinensis (Wang et al., 2007; Zhou et al., 2007; Huang et al., 2012; Jutapruet et al., 2015). However, rapid human population growth and economic development in countries bordering the SCS has intensified pressure on coastal cetacean populations through a wide range of anthropogenic factors, including direct mortality caused by targeted exploitation, fisheries bycatch and vessel collisions, and indirect effects such as habitat destruction, prey depletion, and chemical and noise pollution (Wang and Han, 2007; Marcotte et al., 2015). It is therefore extremely important to establish an improved baseline on the diversity and distribution of coastal cetaceans in the SCS, both to allow assessment of species status for current conservation planning, and to act as a baseline against which to evaluate potential future declines. In order to address this knowledge gap, we conducted a large-scale interview survey of marine resource users in the northern SCS and compared LEK data on cetaceans obtained from this survey with independent data that we collected on cetacean strandings for the same region, to investigate the extent to which fishers' LEK can be used to characterise cetacean status and map cetacean diversity and distributions in a high-diversity and highly threatened marine environment.

\section{Materials and methods}

\subsection{Fisher survey}


We conducted a large-scale questionnaire-based interview survey around the coast of Hainan Island, which covers an area of $35,400 \mathrm{~km}^{2}$ and is separated from mainland China by the Qiongzhou Strait and from Vietnam by Beibu Bay (Fig. 1). Spatial sampling design was based on information about fishing activities around Hainan (e.g. number and location of fishing ports, number of registered fishing boats/families in each region) provided by the China Fishery Statistical Yearbook (The People's Republic of China Ministry of Agriculture, 2012) and Bureau of Ocean and Fishery of Hainan Province. Sixteen big ports across ten cities: Changjiang, Dongfang, Haikou, Ledong, Lingao, Lingshui, Qionghai, Sanya, Wanning and Wenchang were selected to almost equally cover the whole island and to reflect the current distribution of fishing vessels (Fig. 1). As we aimed for the same amount of interviews, we interviewed 20-60 adult fishers in each survey site. Age, sex and ethnicity were not used as selection criteria, to avoid bias. Respondents were only selected for interview if they were professional fishers, they practising fishing as their main source of economic income, and they were born on Hainan or had lived on Hainan for most of their lives. These resource users typically conducted regular fishing activities with respect to both timing and location(s) likely to be inhabited by marine mammals, making them more likely to be familiar with local coastal cetacean populations.

LEK data were collected using a standard questionnaire that took approximately 30 minutes to complete, based on the combined qualitative and quantitative interview techniques described by Chambers (1992) and developed for conservation research in Chinese fishing communities by Turvey et al. (2010, 2012). The questionnaire 
included a combination of multiple choice, short free response, and multi-part questions (Appendix A). We first asked respondents a series of questions about their age, education, fishing gear, fishing area and boat length, how many years ago they started fishing, how many days per year they typically spent fishing, and their perception of the present status of the SCS ecosystem and its fisheries. We then showed them an illustrated handbook including 35 cetacean species that are potentially present in the SCS (Wang, 2011), and asked them to identify the species that they encountered when fishing, together with information on the timing, location, and frequency of sightings. Initial interviews showed that identification of cetacean sightings to species level generally proved difficult for local fishers, and so we grouped the 35 cetacean species in the illustrated handbook into eight categories (Table 1). We used a grid map of the northern SCS (grid size = longitude 0.5 degree $\times$ latitude 0.5 degree, approximately $55 \mathrm{~km} \times 50 \mathrm{~km}$ ) to help respondents locate their cetacean sightings.

Questionnaire surveys were conducted between 30 November and 21 December 2013. Interviews were conducted by both cetacean researchers and trained volunteers. All respondents were interviewed on a one-to-one basis in relaxed, informal settings. Only one person per fishing vessel was interviewed to ensure that interview data were independent. All respondents were informed at the outset about the study's general aims (i.e. collecting LEK data to understand status of cetacean populations) and assured them that data would be kept anonymously; we only conducted interviews following verbal consent of participants. Research design was approved by the 
Research Ethics Committee of the Institute of Deep-Sea Science and Engineering, Chinese Academy of Sciences (permit no.: SIDSSE-SYLL-MMMBL-01).

\subsection{Stranding records}

We also collected all available cetacean stranding records from the northern SCS, including the coastal areas of Fujian, Guangdong, Guangxi, Hainan, Hong Kong, Macau and Taiwan, for the period 2000-2014. Stranding records were collected from local news reports (local newspapers, television or internet) and scientific publications (papers and books), and from the integrated cetacean stranding rescue and record systems for Taiwan and Hong Kong provided by the Taiwan Cetacean Society and Ocean Park Hong Kong, respectively. For each stranding case, we recorded the species identity, number of individuals involved, associated photographic/video documentation, stranding date, locality and data source (Appendix B). Species identity was typically confirmed (or revised if reported inaccurately) on the basis of photographs or videos associated with news reports or publications; when the cetacean involved in a stranding event could not be accurately identified from available images, it was recorded as "unidentified stranded species". All cetacean common and scientific names presented here follow Berta (2015).

\subsection{Data analysis}

We calculated the mean encounter rate ( \pm standard error) for each cetacean category in each survey grid cell to reflect the abundance rankings of cetacean 
categories. Encounter rate was calculated as the total number of sightings for a cetacean category in a specific grid cell divided by the total number of fishers reporting that they fished in that grid cell, expressed as a percentage.

All data were analysed in $\mathrm{R}$ version 3.2.4 ( $\mathrm{R}$ Core Team, 2016). We used chisquared tests to assess whether respondent sighting rate varied between the five west coast counties (Changjiang, Dongfang, Haikou, Ledong, Lingao) and the five east coast counties (Lingshui, Qionghai, Sanya, Wanning, Wenchang), and we conducted analysis of variance (ANOVA) followed by Tukey HSD multiple contrasts to test for significant differences between the ten counties in boat length (representing an indicator of fishing in coastal or offshore waters by respondents) and number of years that respondents have practised fishing. We then used a multivariate GLM model with logit link and a binomial error structure to investigate whether boat length or fishing effort affected the likelihood of respondents having seen cetaceans.

We used the stranding data to assess cetacean species composition and to validate the accuracy of our respondent data for ranking the relative abundances of different cetacean categories in the SCS. We assessed available stranding data for Taiwan, Hong Kong and other Chinese provinces separately, due to the different origin and quality of data from these three regions. We calculated the total number of strandings for each cetacean category, and then compared these stranding data with fishers' cetacean encounter rates using regression analysis.

\section{Results}




\subsection{Overview of fisher survey data}

A total of 510 fishers were interviewed in Hainan: Changjiang $(n=63)$, Dongfang $(\mathrm{n}=49)$, Haikou $(\mathrm{n}=48)$, Ledong $(\mathrm{n}=58)$, Lingao $(\mathrm{n}=55)$, Lingshui $(\mathrm{n}=62)$, Qionghai $(\mathrm{n}=41)$, Sanya $(\mathrm{n}=54)$, Wanning $(\mathrm{n}=31)$, Wenchang $(\mathrm{n}=49)$. Mean respondent age was $42 \pm 13$ years, $98 \%$ of respondents were men, fishing experience began at $17 \pm 5$ years old, and $80 \%$ of respondents were educated to middle school level. Respondents used two categories of fishing vessels: small vessels $(11 \pm 4$ meters, mean $\pm \mathrm{SD}, \mathrm{n}=314$ ) which generally fish within c. $50 \mathrm{~km}$ of ports, and large vessels ( $27 \pm 6$ meters, mean $\pm \mathrm{SD}, \mathrm{n}=196)$ which trawl or purse within c. $200 \mathrm{~km}$ of ports. Significant differences in boat length were present between sites $(F=24.95$, d.f. $=9, \mathrm{p}<0.001)$, with Dongfang, Lingao and Wenchang having larger boats, and Haikou and Wanning having smaller boats (Fig. 2). Mean number of years that respondents had practised fishing was $23 \pm 12$ years, with Tukey HSD multiple contrasts showing no differences between any sites (all $\mathrm{p}>0.05$ ). Respondents spent about half of each year at sea (177 days per year \pm 57 , mean \pm SD) and ranged across 76 grid cells, so can be considered likely to be extremely knowledgeable about biological resources in the SCS.

\subsection{Cetacean distribution}

Overall, $93 \%$ of our respondent sample reported cetacean sightings, representing all eight cetacean categories: other dolphins ( $82 \%$ of respondents), Indo-Pacific humpback dolphin (30\%), Indo-Pacific finless porpoise Neophocaena phocaenoides 
(29\%), baleen whales (19\%), black whales (18\%), beaked whales (4\%), sperm whale (4\%) and grey whale (1\%). The five most frequently reported cetacean categories are shown in Figure 3. All respondents in Ledong and Qionghai reported cetacean sightings, followed in percentage of reported sightings by Lingshui (98\%), Wanning (97\%), Wenchang (96\%), Changjiang (81\%) and Haikou (79\%). The five east coast counties had significantly higher levels of overall reported sightings compared with the five west coast counties $(\chi 2=7.61$, d.f. $=1, p=0.006)$.

The highest level of Indo-Pacific humpback dolphin sightings was reported from Ledong ( $88 \%$ of respondents), following by Sanya (61\%) and Wenchang (47\%); these three sites had significantly higher levels than Changjiang (10\%) and other sites (all < $25 \%, \mathrm{p}<0.001)$. The highest level of Indo-Pacific finless porpoise sightings was reported from Dongfang (55\%) and the lowest level was reported from Wanning (6\%), with a significant difference in sighting levels between east coast counties (39\%) and west coast counties $(19 \%)(\chi 2=23.80$, d.f. $=1, p<0.001)$. For black whales, Wanning and Wenchang had the same highest levels of reported sightings (27\%) and Sanya had the lowest $(6 \%)$, with no difference between east coast and west coast counties $\left(\chi^{2}=1.46\right.$, d.f. $\left.=1, p=0.227\right)$. For other dolphins, Lingshui had the highest level of reported sightings (97\%) and Haikou had the lowest (60\%), with a significant difference in levels between east coast counties $(91 \%)$ and west coast counties $(73 \%)$ $\left(\chi^{2}=25.80\right.$, d.f. $\left.=1, p<0.001\right)$. For baleen whales, Qionghai had the highest level of reported sightings (37\%), whereas no respondents from Dongfang reported sightings, 
and east coast counties (30\%) had significantly higher sighting levels compared with west coast counties $(11 \%)\left(\chi^{2}=27.81\right.$, d.f. $\left.=1, \mathrm{p}<0.001\right)$.

Respondent sighting experience of cetaceans was statistically correlated with both fishing effort and boat length in GLM analysis. Years spent fishing was a significant predictor of increased respondent likelihood of having seen Indo-Pacific humpback dolphin (effect size $=0.037, \mathrm{SE}=0.010, \mathrm{p}<0.001)$, Indo-Pacific finless porpoise $($ effect size $=0.041, \mathrm{SE}=0.009, \mathrm{p}<0.001)$, other dolphins $($ effect size $=0.031, \mathrm{SE}=$ $0.011, \mathrm{p}=0.004)$ and baleen whales (effect size $=0.024, \mathrm{SE}=0.010, \mathrm{p}=0.017)$, although it was not significant in predicting likelihood of having seen black whales ( $p$ $=0.474)$ or "all species" $(p=0.082)$. Increased boat length was a significant predictor of increased respondent likelihood of having seen other dolphins (effect size $=0.063$, $\mathrm{SE}=0.011, \mathrm{p}=0.004)$, but did not predict any other cetacean categories (all $\mathrm{p}>0.05)$

The distributions of reported encounter rates for the four most frequently seen cetacean categories show marked spatial variation (Fig. 4): Indo-Pacific humpback dolphin were reportedly encountered mainly around the Pearl River estuary, Sanniang Bay, Leizhou Bay, and in the southwest coastal waters of Hainan; Indo-Pacific finless porpoise were encountered mainly in the Changhua River estuary on the west coast of Hainan; and other dolphins and baleen whales were instead more commonly encountered along the east coast of Hainan.

Changes to the regional status of cetaceans over time in the SCS were revealed by both respondent perceptions and last-sighting records. For dolphin species (adult length $<4 \mathrm{~m}$, with no recognizable spray column), nearly half of respondents 
considered that abundance had decreased, and very few thought that they had increased (increase: $8 \%$; decrease: 49\%; no change: 12\%; don't know: $26 \%$; no response $=5 \%$ ). Respondents had similar perceptions about whale species (adult length $>4 \mathrm{~m}$, with recognizable spray column), with substantially more respondents again considering that abundance had decreased (increase: $2 \%$; decrease: $28 \%$; no change: $4 \%$; don't know: $42 \%$; no response $=24 \%$ ). A total of 445 cetacean lastsighting records were collected (Changjiang, $n=47$; Dongfang, $n=44$; Haikou, $n=$ 27; Ledong, $\mathrm{n}=58$; Lingao, $\mathrm{n}=47$; Lingshui, $\mathrm{n}=59$; Qionghai, $\mathrm{n}=40$; Sanya, $\mathrm{n}=47$; Wanning, $n=29$; Wenchang, $n=47$ ). Most cetacean last-sighting records dated after $2010(61 \%, \mathrm{n}=272)$, with only 25 records from before 1990, 33 records from between 1990-2000, and 115 records from between 2001-2010 (Fig. 5). For most counties, more than $60 \%$ of last-sighting records dated from after 2010 , but more respondents in Changjiang (19\%), Haikou (30\%) and Lingao (43\%) had not seen cetaceans during this period.

\subsection{Cetacean species composition and abundance rankings of cetacean categories}

In total, information for 1621 stranded cetacean individuals in 1367 separate stranding events between 2000-2014 was compiled for analysis (Table 3). For all administrative regions excluding Taiwan and Hong Kong, 249 stranded cetacean individuals from 193 stranding events (an average of 17.8 events/year) were documented, including 63 in Fujian, 58 in Guangdong, 50 in Hainan, 19 in Guangxi and three in Macau; the data include six identifiable baleen whale species, 19 
identifiable toothed whale or dolphin species, and 10 baleen whale and five toothed whale or dolphin individuals that could not be identified to species level. Pantropical spotted dolphin Stenella attenuata (21 events, 67 individuals), Indo-Pacific finless porpoise (30 events, 30 individuals), and Indo-Pacific humpback dolphin (25 events, 26 individuals) were the most commonly stranded odontocetes across this area; longbeaked and short-beaked common dolphin Delphinus capensis and D. delphis, melonheaded whale Peponocephala electra, pygmy killer whale Feresa attenuata, and Cuvier's beaked whale Ziphius cavirostris were also each recorded once. Bryde's whale Balaenoptera edeni (13 events, 13 individuals) was the most commonly stranded baleen whale species, and blue whale B. musculus and gray whale Eschrichtius robustus were each recorded once. For Hong Kong, 448 stranding events involving 450 cetacean individuals were documented during the same period. These data mainly involved Indo-Pacific finless porpoise (275 individuals, $61 \%$ of strandings) and Indo-Pacific humpback dolphin (145 individuals, 32\% of strandings). For Taiwan, there were 726 stranding events involving 922 cetacean individuals; the most frequently stranded species was Indo-Pacific finless porpoise (129 events, 136 individuals), followed by dwarf sperm whale Kogia simus (71 events, 81 individuals), common bottlenose dolphin Tursiops truncatus (54 events, 54 individuals), Risso's dolphin Grampus griseus (50 events, 55 individuals) and Pantropical spotted dolphin (48 events, 68 individuals). Twelve stranded Indo-Pacific humpback dolphin were recorded from Taiwan during this period. 
Linear regression analyses show significant positive correlations between the percentage of interviewed fishers who reported sightings of each cetacean category and the total number of stranded cetacean individuals representing the corresponding cetacean category for data from Taiwan $\left(\mathrm{R}^{2}=0.863, \mathrm{Y}=0.106 \mathrm{X}+0.500, \mathrm{p}<0.001\right)$, Chinese provinces excluding Taiwan and Hong Kong $\left(\mathrm{R}^{2}=0.970, \mathrm{Y}=0.137 \mathrm{X}+\right.$ $0.111, \mathrm{p}<0.001)$, and the total combined dataset $\left(\mathrm{R}^{2}=0.803, \mathrm{Y}=0.136 \mathrm{X}+0.125, \mathrm{p}\right.$ $=0.003$ ), although no linear relationship was observed for data from Hong Kong alone (Fig. 6).

\section{Discussion}

\subsection{Species distributions}

Using LEK to quantify the distribution of cetaceans presents several potential challenges. Fishers are often unable to identify species accurately, so that there can be uncertainty over the identity of species associated with reported sighting locations. Fishers generally visit fixed fishing areas, meaning that LEK data may violate sampling assumptions that are required to analyse survey effort. Error and bias may also occur between actual and remembered sighting locations and dates, and fishers may only be able to provide a general sighting region when the same species have been observed on more than one occasion. Despite these potential limitations, however, by grouping similar species into categories, we have been able to use LEK data to determine spatial distribution patterns for the four most frequently encountered cetacean categories in the northern SCS (Figs 3 and 4). For example, our results show 
that Indo-Pacific humpback dolphin and Indo-Pacific finless porpoise are mainly distributed in the west coastal waters of Hainan, whereas other dolphins and baleen whales are mainly encountered off the island's east coast close to deeper open ocean waters, suggesting that water depth is likely to play an important role in cetacean species distribution in the SCS.

Our results show that increasing boat length is a significant predictor of whether respondents have seen other dolphins, and there are significant differences in boat length between counties. These two facts together suggest that variation in the reported spatial data for other dolphins might partly be caused by different patterns of fishing activity/effort by respondents in different parts of Hainan, rather than reflecting actual ecological variation in dolphin populations. However, the usefulness of LEK for generating accurate maps of the distribution of some easily identifiable cetacean species is demonstrated by data for Indo-Pacific humpback dolphin. Jefferson (2000) hypothesized that there were about eight populations of humpback dolphins in Chinese waters, but there were no records of humpback dolphins from the waters around Hainan (Jefferson et al., 2008; Chen et al., 2009; Chen et al., 2011). Interestingly however, our interview survey revealed high encounter rates of this species reported by fishers around the southwest coastal waters of Hainan. Following our 2013 fisher survey, humpback dolphins were then recorded for the first time near Hainan in October 2014 during a boat-based field survey (Li et al., 2016) and a stranded individual was also collected in February 2015, confirming the presence of 
this species in the coastal waters of Hainan and providing further independent verification of the general accuracy of fishers' knowledge of cetaceans in the SCS.

\subsection{Species composition}

Our study indicates that LEK is unlikely to be able to provide accurate information on coastal cetacean species richness in a diverse marine system. When we asked fishers to identify cetacean species they had seen from an illustrated handbook, they often found it difficult to do so, frequently using phrases such as "it looked like this species", "maybe this one", and "this sort of dolphin". Respondents were generally only able to confidently distinguish species that differed markedly in skin colour, dorsal fin or other unique morphology, and/or body length. As such, we were only able to gather estimates of cetacean abundance rankings and distribution in this study when species were grouped into categories.

Our study demonstrates that the potential limitations of LEK in determining the species composition of a diverse regional cetacean fauna can be addressed by the use of stranding records, which can often be sourced through a variety of information channels. Our stranding records database for the SCS contains 29 species of cetaceans, including six baleen whales and 23 odontocetes. This number is slightly lower than the SCS cetacean fauna reported by Wang (2011) and Jefferson et al. (2008), who reported between 30 and 32 regionally occurring species, respectively. This slight discrepancy may reflect different reasons. Some stranded animals were unidentifiable to species level due to the preservational state of carcasses or photo quality, and the 
mean number of recorded annual stranding events is low (14 events combined across several other Chinese provinces, compared with 32 and 52 events in Hong Kong and Taiwan, respectively), which probably reflects under-reporting. Using the database established as part of this survey, a new online database for marine mammal stranding records for Hainan was created in July 2015 (http://www.cetacean.csdb.cn/). This database will provide more precise information on regional cetacean diversity and abundance in the future. Alternately, this difference may reflect a recent decline in cetacean biodiversity. Regional anthropogenic pressure on cetaceans may have already caused some species to decline and even disappear. For example, in the $1920 \mathrm{~s}$ the blue whale was subject to commercial whaling in the southern waters of Taiwan, but it has now almost disappeared, and more than 10 humpback whales Megaptera novaeangliae were fished from 1957 to 1958 in Guangdong, but this is now a rare species in the SCS (Wang, 2011).

\subsection{Abundance rankings of cetacean categories}

LEK has been used to estimate both relative abundance patterns (Beaidreai and Levin, 2014) and sometimes also absolute abundance levels (Anadón et al., 2009). It is difficult or impossible to obtain absolute abundance data for cetacean species using LEK, as untrained fishers may be unlikely to be able to count or estimate the number of individuals in cetacean groups with high accuracy (Anadón et al., 2009). However, the abundance rankings for some easily identifiable cetacean species or categories were estimated in this study using the percentage of sightings reported for different 
categories by fishers. Our results suggest that small dolphins are encountered more frequently in the SCS in contrast to larger beaked whales and baleen whales (Figs 2 and 3). This suggestion is supported by independent stranding records from Hong Kong and Taiwan showing that delphinids and phocaenids are the main stranded species, suggesting that small dolphins are the most abundant coastal cetacean species in the northern SCS. Furthermore, we demonstrate that across our entire study area except for Hong Kong, levels of reported cetacean sightings correlate statistically with the independent measure of cetacean abundance represented by stranding records. This correlation provides crucial validation of the general accuracy of our regional cetacean LEK dataset, and confirms that LEK can provide accurate abundance ranking information about cetaceans. Although overall levels of reported cetacean sightings do not correlate statistically with independent stranding records around Hong Kong, Indo-Pacific finless porpoise and Indo-Pacific humpback dolphinboth had relatively high observed regional stranding rates, were both widely reported from this region by respondents in our study, and are known to be relatively abundant compared with other cetacean species based on independent survey data (Wang, 2011).

This validation suggests that other, non-verified quantitative LEK data obtained from our study on the regional status of cetaceans in the northern SCS may also be accurate. Analysis of last-sighting data from the ten surveyed counties around Hainan showed that more respondents in Haikou, Lingao and Changjiang had not seen cetaceans in recent years, indicating that cetaceans in waters off these three northwest 
counties might have been affected more substantially by increasing anthropogenic pressure in marine areas close to mainland China. In particular, data for this region on respondent perceptions of cetacean declines and the long time period since many respondents have observed cetaceans together raise concerns about the local status of cetacean populations, and regional cetacean population trends should be investigated further through future field surveys.

\subsection{Conservation and whale-watching}

Rapid economic growth in China and other Southeast Asian countries, along with rising anthropogenic pressures such as fishing, eutrophication, habitat destruction and shipping ( $\mathrm{Ng}$ and Tan, 2000; Pitcher et al., 2000), have direct negative ecological impacts on cetaceans (Nowacek et al., 2007; Williams et al., 2008; Baird et al., 2015). However, other than the studies of $\mathrm{Ng}$ and Leung (2003), the impacts of these anthropogenic pressures on coastal cetaceans in the SCS have so far been the focus of little research. The findings of our study should be used to establish a conservation framework for cetaceans in the northern SCS. This aim could be achieved through the delineation of marine protected areas (MPAs) in locations where cetaceans occur in relatively high abundance, and our LEK and field data are currently being used to inform potential establishment of an MPA for Indo-Pacific humpback dolphin in coastal waters off southwest Hainan.

Cetacean-watching tourism may be an alternative to a local fishing-based economy around parts of Hainan. Cetacean-watching is commonly presented as a benign 
method for enhancing public attitudes toward the marine environment, and it is increasingly popular in cetacean-rich western countries including Canada, the United States and Australia (Hoyt, 2001). Hainan is experiencing economic growth and tourism development, and cetacean-watching has the potential to be a new source of revenue. However, this type of tourism activity is currently only available in the northern SCS on the east coast of Taiwan and in Sanniang Bay, Guangxi (Tseng et al., 2011; Chen et al., 2016). Although cetacean-watching needs to be well regulated, this study provides important information to aid its potential establishment in Hainan. Our results indicate that there is potential for cetacean-watching for Indo-Pacific humpback dolphin and Indo-Pacific finless porpoise in southwest Hainan, and possibly for baleen whales and other dolphins in eastern Hainan.

\section{Conclusion}

Although interview data on fishers' LEK are likely to be both incomplete and biased, our study shows that such data can still provide quantitative information on both diversity and distribution for several coastal cetacean species or categories, such as Indo-Pacific humpback dolphin in the northern SCS. Interview surveys therefore represent an effective, rapid survey method for obtaining information on key parameters of cetacean ecology across large geographic regions, especially for regions where traditional cetacean field surveys have rarely been conducted.

As LEK and stranding data are now demonstrated to constitute a good indicator of regional cetacean status, there is a need to establish a cetacean database for the whole 
of the SCS, ideally also including data from boat-based and/or plane-based visual surveys and boat-based acoustic surveys, to provide more accurate information about species composition, abundance and distribution. Understanding the relationship between cetacean distribution patterns and environmental factors is becoming increasingly important in the changing ecosystem of the SCS, and this region also requires a novel policy framework that should include ecological information together with analysis of the current and future ecosystem services associated with regional cetacean presence.

\section{Acknowledgements}

We express our thanks to Ocean Park Conservation Foundation Hong Kong for providing stranding data from Hong Kong, and the Blue Ribbon Ocean Conservation Society of Sanya for their help in recruiting volunteers. We are also grateful to Wang Renyi, Xu Xiqian, Deng Hualan, Gou Lifang, Wu Jianjun, Zuo Chen, Lai Wenyi, and many other volunteers for their assistance with the questionnaire survey. This research was financially supported by the National Natural Science Foundation of China (41422604, 41306169, 41406182), the "Hundred Talents Programme" of the Chinese Academy of Sciences (SIDSSE-BR-315 201201, Y410012), the Knowledge Innovation Programme of the Chinese Academy of Sciences (SIDSSE-316 201210), the Science and Technology Cooperation Project of Sanya City and the Chinese Academy of Sciences (2013YD75), the Marine Development by Science and Technology Project of Hainan Province (XH201423), the Advanced Project in Young 
Talent of the Sanya Institute of Deep-Sea Science and Engineering, Chinese Academy of Sciences (SIDSSE-QN-201304), a Major Science and Technology Project in Hainan Province (grant no. ZDKJ2016009-1-1), and Ocean Park Conservation Foundation Hong Kong (MM03-1415, MM02-1516).

\section{Appendix A. Fishermen survey questionnaire (English version).}

\section{Appendix B. Stranding data.}

\section{References}

1. Anadón, J.D., Giménez, A., Ballestar, R., Pérez, I., 2009. Evaluation of local ecological knowledge as a method for collecting extensive data on animal abundance. Conserv. Biol. 23, 617-625.

2. Aragones, L.V., Jefferson, T.A., Marsh, H., 1997. Marine mammal survey techniques applicable in developing countries. Asian Mar. Biol. 14, 15-39.

3. Baird, R.W., Mahaffy, S.D., Gorgone, A.M., Cullins, T., Mcsweeney, D.J., Oleson, E.M., Bradford, A.L., Barlow, J., Webster, D.L., 2015. False killer whales and fisheries interactions in Hawaiian waters: Evidence for sex bias and variation among populations and social groups. Mar. Mamm. Sci. 31, 579-590.

4. Beaidreai, A.H., Levin, P.S., 2014. Advancing the use of local ecological knowledge for assessing data-poor species in coastal ecosystems. Ecol. Appl. 24, $244-256$

5. Berkes, F., Colding, J., Folke, C., 2000. Rediscovery of traditional ecological 
knowledge as adaptive management. Ecol. Appl. 10, 1251-1262.

6. Berta, A., 2015. Whales, Dolphins, and Porpoises: A natural history and species guide. The University of Chicago Press, Chicago.

7. Buckland, S.T., Anderson, D.R., Burnham, K.P., Laake, J.L., 1993. Distance sampling: Estimating abundance of biological populations. Chapman and Hall, London.

8. Caruso, N., Luengos Vidal, E., Guerisoli, M., Lucherini, M., 2016. Carnivore occurrence: do interview-based surveys produce unreliable results? Oryx 51, 240245.

9. Chambers, R., 1992. Rapid appraisal: rapid, relaxed and participatory. Discussion paper 311. Institute of Development Studies, University of Sussex, Brighton.

10. Channell, R., Lomolino, M.V., 2000. Dynamic biogeography and conservation of endangered species. Nature 403, 84-86.

11. Chen, B., Zheng, D., Yang, G., Xu, X., Zhou, K., 2009. Distribution and conservation of the Indo-Pacific humpback dolphins in China. Integr. Zool. 4, 240-247.

12. Chen, B., Xu, X., Jefferson, T.A., Olson, P.A., Qin, Q., Zhang, H., He, L., Yang, G., 2016. Conservation Status of the Indo-Pacific Humpback Dolphin (Sousa chinensis) in the Northern Beibu Gulf, China. Adv. Mar. Biol. 73, 119-139.

13. Chen, T., Qiu, Y., Jia, X., Hung, S.K., Liu, W., 2011. Distribution and group dynamics of Indo-Pacific humpback dolphin (Sousa chinensis) in the western Pearl River Estuary, China. Mamm. Biol. 76, 93-96. 
14. The People's Republic of China Ministry of Agriculture., 2012. China Fishery Statistical Yearbook. China Agricultural Press, Beijing.

15. Fearnbach, H., Durban, J., Parsons, K., Claridge, D., 2012. Photographic markrecapture analysis of local dynamics within an open population of dolphins. Ecol. Appl. 22, 1689-1700.

16. Gerhardinger, L.C., Godoy, E.A.S., Jones, P.J.S., 2009. Local ecological knowledge and the management of marine protected areas in Brazil. Ocean Coast. Manag. 52, 154-165.

17. Goetz, S., Read, F.L., Santos, M.B., Pita, C., Pierce, G.J., 2014. Cetacean-fishery interactions in Galicia (NW Spain): results and management implications of a face-to-face interview survey of local fishers. ICES J. Mar. Sci. 71, 604-617.

18. Gonzalvo, J., Giovos, I., Moutopoulos, D.K., 2014. Fishermen's perception on the sustainability of small-scale fisheries and dolphin-fisheries interactions in two increasingly fragile coastal ecosystems in western Greece. Aquat. Conserv. Mar. Freshw. Ecosyst. 25, 91-106.

19. Hao, Y., Wang, K., Han, J., Zheng, J., Xian, Y., Yao, Z., Lu, Z., Li, H., Zhang, X., 2011. Marine mammal researches in China. Acta Theriol. Sinica. 31, 20-36.

20. Hoyt, E., 2001. Whale watching 2001: worldwide tourism numbers, expenditures, and expanding socioeconomic benefits. International Fund for Animal Welfare, Yarmouth port.

21. Huang, S.L., Karczmarski, L., Chen, J., Zhou, R., Lin, W., Zhang, H., Li, H., Wu, Y., 2012. Demography and population trends of the largest population of Indo- 
Pacific humpback dolphins. Biol. Conserv. 147, 234-242.

22. Inglis, J.T., 1993. Traditional ecological knowledge: concepts and cases. International program on traditional ecological knowledge and international development research centre, Canadian Museum of Nature, Ottawa, Ontario, Canada.

23. Jefferson, T.A., 2000. Population biology of the Indo-Pacific hump-backed dolphin in Hong Kong waters. Wildlife Monogr. 144, 1-65.

24. Jefferson, T.A., Webber, M.A., Pitman, R.L., 2008. Marine mammals of the world: a comprehensive guide to their identification. Academic Press, London.

25. Johannes, R.E., Freeman, M.M.R., Hamilton, R.J., 2000. Ignore fishers' knowledge and miss the boat. Fish Fish. 1, 257-271.

26. Jutapruet, S., Huang, S.L., Li, S., Lin, M., Kittiwattanawong, K., Pradit, S., 2015. Population size and habitat characteristics of the Indo-Pacific humpback dolphins (Sousa chinensis) off Donsak, Surat Thani, Thailand. Aquat. Mamm.41, 129-142.

27. Li, S., Akamatsu, T., Dong, L., Wang, K., Wang, D., Kimura, S., 2010. Widespread passive acoustic detection of Yangtze Indo-Pacific finless porpoises using miniature stereo acoustic data-loggers: a review. J. Acoust. Soc. Am. 128, $1476-1482$.

28. Li, S., Lin, M., Xu, X., Xing, L., Zhang, P., Gozlan, R.E., Huang, S.L., Wang, D., 2016. First record of the Indo-Pacific humpback dolphins (Sousa chinensis) southwest of Hainan Island, China. Mar. Biodivers. Rec. 9, 1-6.

29. Liu, M., Lin, M., Turvey, S.T., Li, S., 2016. Fishers' knowledge as an information 
source to investigate by-catch of marine mammals in the South China Sea. Anim. Conserv. 20, 182-192.

30. Lopez, A., Pierce, G.J., Santos, M.B., Gracia, J., Guerra, A., 2003. Fishery bycatches of marine mammals in Galician waters: results from on-board observations and an interview survey of fishermen. Biol. Conserv. 111, 25-40.

31. Mace, G.M., Collar, N.J., Gaston, K.J., Hilton-Taylor, C., Akcakaya, H.R., Leader-Williams, N., Milner-Gulland, E.L., Stuart, S.N., 2008. Quantification of extinction risk: IUCN's system for classifying threatened species. Conserv. Biol. $22,1424-1442$.

32. Marin, K., Coon, A., Fraser, D.J., 2017. Traditional ecological knowledge reveals the extent of sympatric lake trout diversity and habitat preferences. Ecol. Soc. 22, 20.

33. Marcotte D., Hung, SK., Caquard, S., 2015. Mapping cumulative impacts on Hong Kong's pink dolphin population. Ocean Coast. Manag. 109, 51-63.

34. Mellinger, D.K., Stafford, K.M., Moore, S.E., 2007. An overview of fixed passive acoustic observation methods for cetaceans. Oceanography 20, 36-45.

35. Newing, H., 2011. Conducting research in conservation: a social science perspective. Routledge, Abingdon.

36. Ng, P.K.L., Tan, K.S., 2000. The state of marine biodiversity in the South China Sea. Raffles B. Zool. 48, 3-7.

37. Ng, S.L., Leung, S., 2003. Behavioral response of Indo-Pacific humpback dolphin (Sousa chinensis) to vessel traffic. Mar. Environ. Res. 56, 555-567. 
38. Nowacek, D.P., Thorne, L.H., Johnston, D.W., Tyack, P.L., 2007. Responses of cetaceans to anthropogenic noise. Mammal. Rev. 37, 81-115.

39. Olsson, P., Folke, C., 2001. Institutional dynamics for ecosystem management: a study of Lake Racken watershed, Sweden. Ecosystems 4, 85-104.

40. Pitcher, T.J., Watson, R., Haggan, N., Guénette, S., Kennish, R., Sumaila, U.R., David, C., Keith, W., Albert, L., 2000. Marine reserves and the restoration of fisheries and marine ecosystems in the South China Sea. B. Mar. Sci. 66, 543-566.

41. R core team., 2016. R: a language and environment for statistical computing. $\mathrm{R}$ Foundation for Statistical Computing, Vienna.

42. Richman, N.I., Gibbons, J.M., Turvey, S.T., Akamatsu, T., Ahmed, B., Mahabu, E., Smith, B.D., Jones, J.P.G., 2014. To see or not to see: investigating detectability of Ganges River dolphins using a combined visual-acoustic survey. PLoS ONE 9, e96811.

43. Sanchez-Carnero, N., Rodríguez-Perez, D., Counago, E., Barzik, F., Freire, J., 2016. Species distribution models and local ecological knowledge in marine protected areas: The case of Os Minarzos (Spain). Ocean Coast. Manag. 124, 6677.

44. Schipper, J., Chanson, J.S., Chiozza, F., Cox, N.A., Hoffmann, M., Katariya, V., Lamoreux, J., 2008. The status of the world's land and marine mammals: Diversity, threat, and knowledge. Science 322, 225-230.

45. Sousa, M.E.M., Martins, B.M.L., Femandes, M.E.B., 2013. Meeting the giants: The need for local ecological knowledge (LEK) as a tool for the participative 
management of manatees on Marajó Island, Brazilian Amazonian coast. Ocean Coast. Manag. 86, 53-60.

46. Souza, S.P., Begossi, A., 2007. Whales, dolphins or fishes? The ethnotaxonomy of cetaceans in São Sebastião, Brazil. J. Ethnobiol. Ethnome. 3, 1-15.

47. Taylor, B.L., Martinez, M., Gerrodette, T., Barlow, J., Hrovat, Y.N., 2007. Lessons from monitoring trends in abundance of marine mammals. Mar. Mamm. Sci. 23, 157-175.

48. Tseng, Y., Huang, Y., Kyle, G., Yang, M., 2011. Modeling the impacts of cetacean-focused tourism in Taiwan: observations from cetacean watching boats: 2002-2005. Environ. Manage. 47, 56-66.

49. Turvey, S.T., Fernández-Secades, C., Nuñez-Miño, J.M., Hart, T., Martinez, P., Brocca, J.L., Young, R.P., 2014. Is local ecological knowledge a useful conservation tool for small mammals in a Caribbean multicultural landscape? Biol. Conserv. 169, 189-197.

50. Turvey, S.T., Barrett, L.A., Hart, T., Collen, B., Hao, Y.J., Zhang, L., Zhang, X., Wang, X., Huang, Y., Zhou, K., Wang, D., 2010. Spatial and temporal extinction dynamics in a freshwater cetacean. P. Roy. Soc. B. 277, 3139-3147.

51. Turvey, S.T., Risley, C.L., Barrett, L.A., Hao, Y.J., Wang, D., 2012. River dolphins can act as population trend indicators in degraded freshwater systems. PLoS ONE 7, e37902.

52. Wang, J.Y., Yang, S.C., Hung, S.K., Jefferson, T.A., 2007. Distribution, abundance and conservation status of the eastern Taiwan Strait population of 
Indo-Pacific humpback dolphins, Sousa chinensis. Mammalia 71, 157-165.

53. Wang, P.L., 2011. Chinese cetaceans. Chemical Industry Press, Beijing.

54. Wang, P.L., Han, J.B., 2007. Present status of distribution and protection of Chinese white dolphins (Sousa chinensis) population in Chinese waters. Mar. Environ. Sci. 26, 484-487.

55. Williams, R., Hall, A., Winship, A., 2008. Potential limits to anthropogenic mortality of small cetaceans in coastal waters of British Columbia. Can. J. Fish. Aquat. Sci. 65, 1867-1878.

56. Ziembicki, M.R., Woinarski, J.C.Z., Mackey, B., 2013. Evaluating the status of species using indigenous knowledge: novel evidence for major native mammal declines in northern Australia. Biol. Conserv. 157, 780-792.

57. Zhou, K., Xu, X., Tian, C., 2007. Distribution and abundance of Indo-Pacific humpback dolphins in Leizhou Bay, China. New. Zeal. J. Zool. 34, 35-42. 
Table 1. Categories of cetaceans likely to be present in the South China Sea, that were used in our questionnaires. Some species were listed individually as they are easily identifiable due to distinctive skin colour or head morphology, or absence of dorsal fin.

\begin{tabular}{|c|c|c|c|}
\hline Group categories & Code & Common name & Latin name \\
\hline $\begin{array}{l}\text { Indo-Pacific finless } \\
\text { porpoise }\end{array}$ & NPH & Indo-Pacific finless porpoise & Neophocaena phocaenoides \\
\hline $\begin{array}{l}\text { Indo-Pacific humpback } \\
\text { dolphin }\end{array}$ & $\mathrm{SCH}$ & $\begin{array}{l}\text { Indo-Pacific humpback } \\
\text { dolphin }\end{array}$ & Sousa chinensis \\
\hline Grey whale & ERO & Grey whale & Eschrichtius robustus \\
\hline Sperm whale & PMA & Sperm whale & Physeter macrocephalus \\
\hline Black whales & BLW & Killer whale & Orcinus orca \\
\hline & & $\begin{array}{l}\text { Short-finned pilot whale } \\
\text { Pygmy killer whale } \\
\text { Melon-headed whale } \\
\text { False killer whale }\end{array}$ & $\begin{array}{l}\text { Globicephala macrorhynchus } \\
\text { Feresa attenuata } \\
\text { Peponocephala electra } \\
\text { Pseudorca crassidens }\end{array}$ \\
\hline Beaked whales & BEW & $\begin{array}{l}\text { Cuvier's beaked whale } \\
\text { Longman's beaked whale } \\
\text { Blainville's beaked whale } \\
\text { Ginkgo-toothed beaked } \\
\text { whale }\end{array}$ & $\begin{array}{l}\text { Ziphius cavirostris } \\
\text { Indopacetus pacificus } \\
\text { Mesoplodon densirostris } \\
\text { Mesoplodon ginkgodens }\end{array}$ \\
\hline Other dolphins & OTD & & \\
\hline Other baleen whales & BAW & & \\
\hline
\end{tabular}


Table 2. Final multivariate generalized linear models (GLMs) investigating respondent sighting experience of cetaceans around Hainan.

\begin{tabular}{|c|c|c|c|c|}
\hline Predictor & Estimate & SE & z-value & P-value \\
\hline \multicolumn{5}{|c|}{ 1. Indo-Pacific humpback dolphin } \\
\hline Intercept & -3.353 & 0.553 & -6.062 & $<0.001$ \\
\hline Haikou & 0.386 & 0.623 & 0.619 & 0.536 \\
\hline Lingao & 0.951 & 0.553 & 1.720 & 0.086 \\
\hline Dongfang & 1.073 & 0.573 & 1.872 & 0.061 \\
\hline Ledong & 4.329 & 0.596 & 7.262 & $<0.001$ \\
\hline Sanya & 2.674 & 0.524 & 5.105 & $<0.001$ \\
\hline Lingshui & 0.806 & 0.550 & 1.465 & 0.143 \\
\hline Wanning & -0.958 & 1.110 & -0.863 & 0.388 \\
\hline Qionghai & 0.287 & 0.647 & 0.444 & 0.657 \\
\hline Wenchang & 2.017 & 0.551 & 3.660 & $<0.001$ \\
\hline Boat length & 0.011 & 0.014 & 0.740 & 0.459 \\
\hline Fishing year & 0.037 & 0.010 & 3.838 & $<0.001$ \\
\hline \multicolumn{5}{|c|}{ 2. Indo-Pacific finless porpoise } \\
\hline Intercept & -1.447 & 0.409 & -3.538 & $<0.001$ \\
\hline Haikou & -0.114 & 0.424 & -0.268 & 0.789 \\
\hline Lingao & 0.136 & 0.415 & 0.328 & 0.743 \\
\hline Dongfang & 1.108 & 0.422 & 2.626 & 0.009 \\
\hline Ledong & -0.082 & 0.393 & -0.209 & 0.834 \\
\hline Sanya & -0.622 & 0.431 & -1.444 & 0.149 \\
\hline Lingshui & -0.855 & 0.434 & -1.969 & 0.049 \\
\hline Wanning & -2.006 & 0.787 & -2.547 & 0.011 \\
\hline Qionghai & -1.430 & 0.556 & -2.575 & 0.010 \\
\hline Wenchang & -0.270 & 0.455 & -0.594 & 0.553 \\
\hline Boat length & -0.011 & 0.014 & 0.749 & 0.454 \\
\hline Fishing year & 0.041 & 0.009 & 4.699 & $<0.001$ \\
\hline \multicolumn{5}{|l|}{ 3. Black whales } \\
\hline Intercept & -1.873 & 0.520 & -3.600 & $<0.001$ \\
\hline Haikou & 0.449 & 0.564 & 0.796 & 0.426 \\
\hline Lingao & 1.057 & 0.523 & 2.021 & 0.043 \\
\hline Dongfang & 0.586 & 0.557 & 1.052 & 0.293 \\
\hline Ledong & -0.276 & 0.617 & -0.447 & 0.655 \\
\hline Sanya & -0.725 & 0.719 & -1.009 & 0.313 \\
\hline Lingshui & 1.099 & 0.492 & 2.232 & 0.026 \\
\hline Wanning & 0.391 & 0.639 & 0.612 & 0.541 \\
\hline Qionghai & 0.954 & 0.542 & 1.761 & 0.078 \\
\hline Wenchang & 1.107 & 0.542 & 2.042 & 0.041 \\
\hline Boat length & -0.003 & 0.015 & -0.193 & 0.847 \\
\hline Fishing year & -0.007 & 0.010 & -0.715 & 0.474 \\
\hline
\end{tabular}




\begin{tabular}{|c|c|c|c|c|}
\hline Predictor & Estimate & SE & z-value & P-value \\
\hline \multicolumn{5}{|c|}{ 4. Other dolphins } \\
\hline Intercept & -0.556 & 0.489 & -1.136 & 0.256 \\
\hline Haikou & -0.309 & 0.435 & -0.710 & 0.478 \\
\hline Lingao & 0.502 & 0.544 & 0.923 & 0.356 \\
\hline Dongfang & -0.523 & 0.468 & -1.116 & 0.265 \\
\hline Ledong & -0.228 & 0.414 & -0.551 & 0.582 \\
\hline Sanya & 0.121 & 0.460 & 0.262 & 0.793 \\
\hline Lingshui & 2.399 & 0.781 & 3.073 & 0.002 \\
\hline Wanning & 1.664 & 0.694 & 2.398 & 0.017 \\
\hline Qionghai & 2.002 & 0.789 & 2.538 & 0.011 \\
\hline Wenchang & 1.045 & 0.693 & 1.508 & 0.132 \\
\hline Boat length & 0.063 & 0.021 & 3.065 & 0.002 \\
\hline Fishing year & 0.031 & 0.011 & 2.889 & 0.004 \\
\hline \multicolumn{5}{|c|}{ 5. Baleen whales } \\
\hline Intercept & -3.978 & 0.688 & -5.785 & $<0.001$ \\
\hline Haikou & 0.993 & 0.763 & 1.301 & 0.193 \\
\hline Lingao & 1.180 & 0.703 & 1.679 & 0.093 \\
\hline Dongfang & -14.686 & 557.456 & -0.026 & 0.979 \\
\hline Ledong & 1.571 & 0.682 & 2.303 & 0.021 \\
\hline Sanya & 1.449 & 0.691 & 2.098 & 0.036 \\
\hline Lingshui & 2.136 & 0.658 & 3.247 & 0.001 \\
\hline Wanning & 2.498 & 0.715 & 3.492 & $<0.001$ \\
\hline Qionghai & 2.461 & 0.678 & 3.632 & $<0.001$ \\
\hline Wenchang & 1.962 & 0.687 & 2.854 & 0.004 \\
\hline Boat length & 0.025 & 0.014 & 1.798 & 0.072 \\
\hline Fishing year & 0.024 & 0.010 & 2.381 & 0.017 \\
\hline \multicolumn{5}{|c|}{ 6. All cetacean species } \\
\hline Intercept & 0.303 & 0.618 & 0.491 & 0.624 \\
\hline Haikou & 0.124 & 0.506 & 0.244 & 0.807 \\
\hline Lingao & 1.054 & 0.703 & 1.499 & 0.134 \\
\hline Dongfang & 0.803 & 0.649 & 1.237 & 0.216 \\
\hline Ledong & 18.147 & 1404.010 & 0.013 & 0.990 \\
\hline Sanya & 0.718 & 0.575 & 1.249 & 0.212 \\
\hline Lingshui & 2.699 & 1.060 & 2.546 & 0.011 \\
\hline Wanning & 2.282 & 1.084 & 2.105 & 0.035 \\
\hline Qionghai & 18.138 & 1661.241 & 0.011 & 0.991 \\
\hline Wenchang & 1.306 & 0.832 & 1.570 & 0.116 \\
\hline Boat length & 0.039 & 0.028 & 1.403 & 0.161 \\
\hline Fishing year & 0.026 & 0.015 & 1.740 & 0.082 \\
\hline
\end{tabular}

Changjiang represents the randomly selected reference county. 
Table 3. Stranding information for cetaceans in Hainan, Guangdong, Guangxi, Fujian, Macao (collectively "Other Provinces”), Hong Kong and Taiwan between 2000-2014.

$\mathrm{T}=$ stranding events; $\mathrm{NM}=$ number of individuals.

\begin{tabular}{|c|c|c|c|c|c|c|c|}
\hline \multirow{2}{*}{ Common name } & \multirow{2}{*}{ Scientific name } & \multicolumn{2}{|c|}{ Other Provinces } & \multicolumn{2}{|c|}{ Hong Kong } & \multicolumn{2}{|c|}{ Taiwan } \\
\hline & & $\mathbf{T}$ & NM & $\mathbf{T}$ & NM & $\mathbf{T}$ & NM \\
\hline Grey whale & Eschrichtius robustus & 1 & 1 & 0 & 0 & 0 & 0 \\
\hline Common minke whale & Balaenoptera acutorostrata & 5 & 5 & 0 & 0 & 4 & 4 \\
\hline Bryde's whale & Balaenoptera edeni & 13 & 13 & 1 & 1 & 1 & 1 \\
\hline Blue whale & Balaenoptera musculus & 1 & 1 & 0 & 0 & 0 & 0 \\
\hline Omura's whale & Balaenoptera omurai & 4 & 4 & 1 & 1 & 5 & 5 \\
\hline Humpback whale & Megaptera novaeangliae & 3 & 3 & 0 & 0 & 1 & 1 \\
\hline Long-beaked common dolphin & Delphinus capensis & 1 & 1 & 1 & 1 & 5 & 5 \\
\hline Short-beaked common dolphin & Delphinus delphis & 1 & 1 & 0 & 0 & 3 & 3 \\
\hline Pygmy killer whale & Feresa attenuata & 1 & 2 & 0 & 0 & 32 & 37 \\
\hline False killer whale & Pseudorca crassidens & 3 & 4 & 2 & 2 & 16 & 16 \\
\hline Short-finned pilot whale & Globicephala macrorhynchus & 9 & 9 & 0 & 0 & 22 & 30 \\
\hline Risso's dolphin & Grampus griseus & 13 & 14 & 1 & 1 & 50 & 55 \\
\hline Fraser's dolphin & Lagenodelphis hosei & 0 & 0 & 0 & 0 & 44 & 45 \\
\hline Melon-headed whale & Peponocephala electra & 1 & 1 & 0 & 0 & 9 & 17 \\
\hline Indo-Pacific humpback dolphin & Sousa chinensis & 25 & 26 & 144 & 145 & 10 & 12 \\
\hline Pantropical spotted dolphin & Stenella attenuata & 21 & 67 & 1 & 1 & 48 & 68 \\
\hline Striped dolphin & Stenella coeruleoalba & 0 & 0 & 2 & 2 & 7 & 8 \\
\hline Rough-toothed dolphin & Steno bredanensis & 3 & 3 & 3 & 3 & 35 & 44 \\
\hline Spinner dolphin & Stenella longirostris & 7 & 8 & 0 & 0 & 9 & 9 \\
\hline Indo-Pacific bottlenose dolphin & Tursiops aduncus & 10 & 13 & 1 & 1 & 13 & 14 \\
\hline Common bottlenose dolphin & Tursiops truncatus & 6 & 6 & 4 & 4 & 54 & 54 \\
\hline Sperm whale & Physeter macrocephalus & 4 & 4 & 1 & 1 & 5 & 5 \\
\hline Pygmy sperm whale & Kogia breviceps & 9 & 9 & 2 & 2 & 31 & 140 \\
\hline Dwarf sperm whale & Kogia simus & 4 & 4 & 0 & 0 & 71 & 81 \\
\hline Longman's beaked whale & Indopacetus pacificus & 0 & 0 & 0 & 0 & 2 & 3 \\
\hline Blainville's beaked whale & Mesoplodon densirostris & 3 & 4 & 0 & 0 & 17 & 17 \\
\hline Ginkgo-toothed beaked whale & Mesoplodon ginkgodens & 0 & 0 & 0 & 0 & 11 & 14 \\
\hline Cuvier's beaked whale & Ziphius cavirostris & 1 & 1 & 0 & 0 & 12 & 12 \\
\hline Indo-Pacific finless porpoise & Neophocaena phocaenoides & 30 & 30 & 274 & 275 & 129 & 136 \\
\hline Unidentified toothed whales & - & 4 & 5 & 6 & 6 & 4 & 4 \\
\hline Unidentified baleen whales & - & 10 & 10 & 4 & 4 & 76 & 82 \\
\hline Total & & 193 & 249 & 448 & 450 & 726 & 922 \\
\hline
\end{tabular}




\section{FIGURE LEGENDS}

Fig. 1. Survey sites in Hainan (names inside indicate survey counties; names outside indicate interview localities).

Fig. 2. Boxplot of respondent boat length and fishing effort. The same letter indicates no significance between counties, while different letters indicate significant differences $(P<0.05)$. No significant differences were observed in fishing effort between sites with Tukey HSD multiple contrasts. CJ: Changjiang, DF: Dongfang, HK: Haikou, LD: Ledong, LG: Lingao, LS: Lingshui, QH: Qionghai, SY: Sanya, WC: Wenchang, WN: Wanning.

Fig. 3. Proportion of respondents who reported sightings of different cetacean categories (BAW: baleen whales, BLW: black whales, NPH: Indo-Pacific finless porpoise, OTD: other dolphins, $\mathrm{SCH}$ : Indo-Pacific humpback dolphin). CJ: Changjiang, DF: Dongfang, HK: Haikou, LD: Ledong, LG: Lingao, LS: Lingshui, QH: Qionghai, SY: Sanya, WC: Wenchang, WN: Wanning. Asterisks indicate counties with significantly lower awareness/experience levels than Changjiang; stars indicate counties with significantly higher levels.

Fig. 4. Distribution maps of encounter rate (i.e. proportion of respondents who reported sightings of specific cetacean categories against the total number of respondents fishing in each grid cell) for four cetacean categories (a): Indo-Pacific 
humpback dolphin, (b): Indo-Pacific finless porpoise, (c): baleen whales, (d): other dolphins.

Fig. 5. Frequency distributions for cetacean last-sighting records across 10 counties in Hainan for the period 1980-2013.

Fig. 6. Linear regression of respondent encounter rate of different cetacean categories against number of reported strandings for different geographic regions around the SCS (BAW, baleen whales; BEW, beaked whales; BLW, black whales; ERO, grey whale; NPH, Indo-Pacific finless porpoise; OTD, other dolphins; PMA, sperm whale; $\mathrm{SCH}$, Indo-Pacific humpback dolphin). 


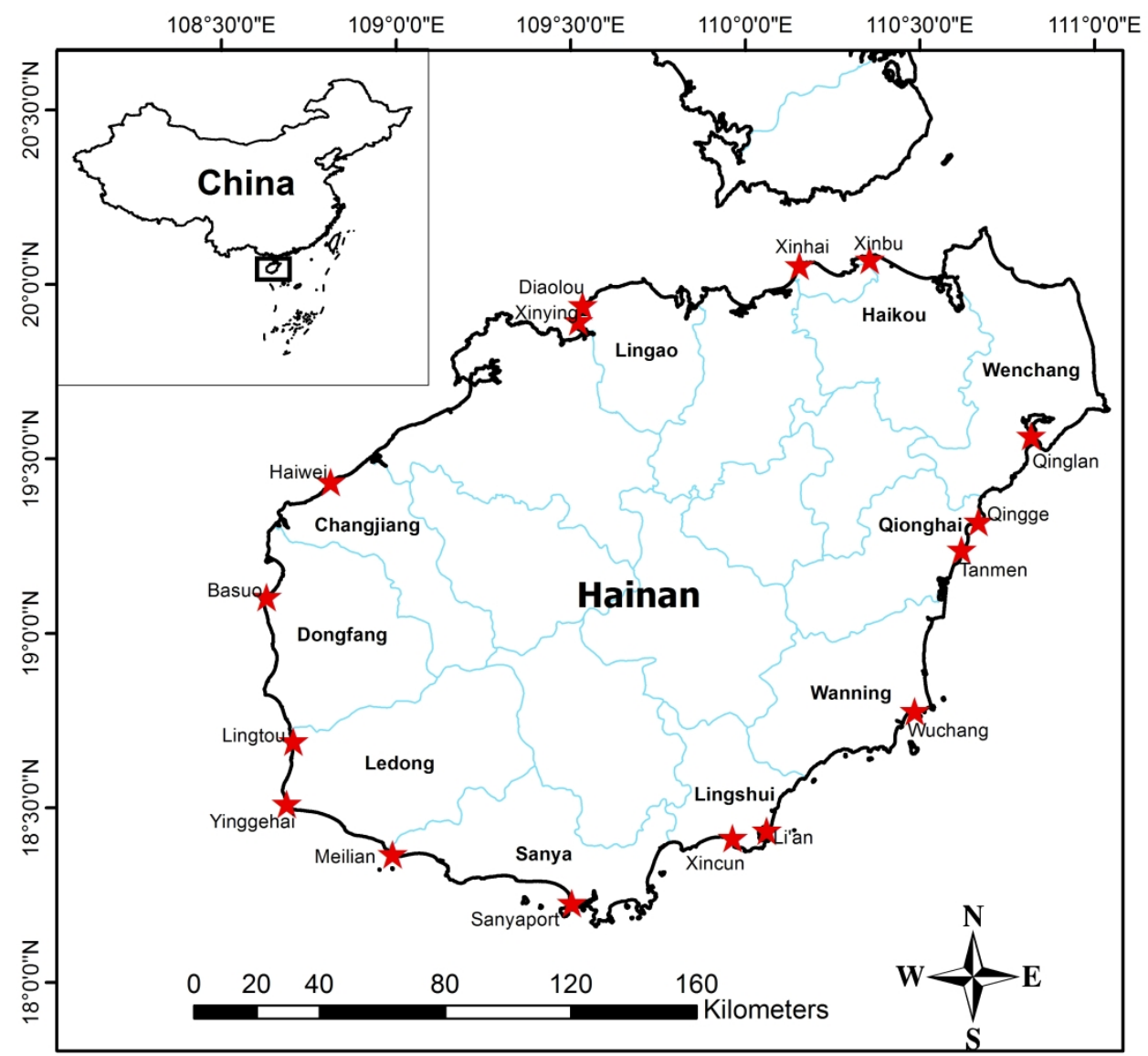

Fig. 1 

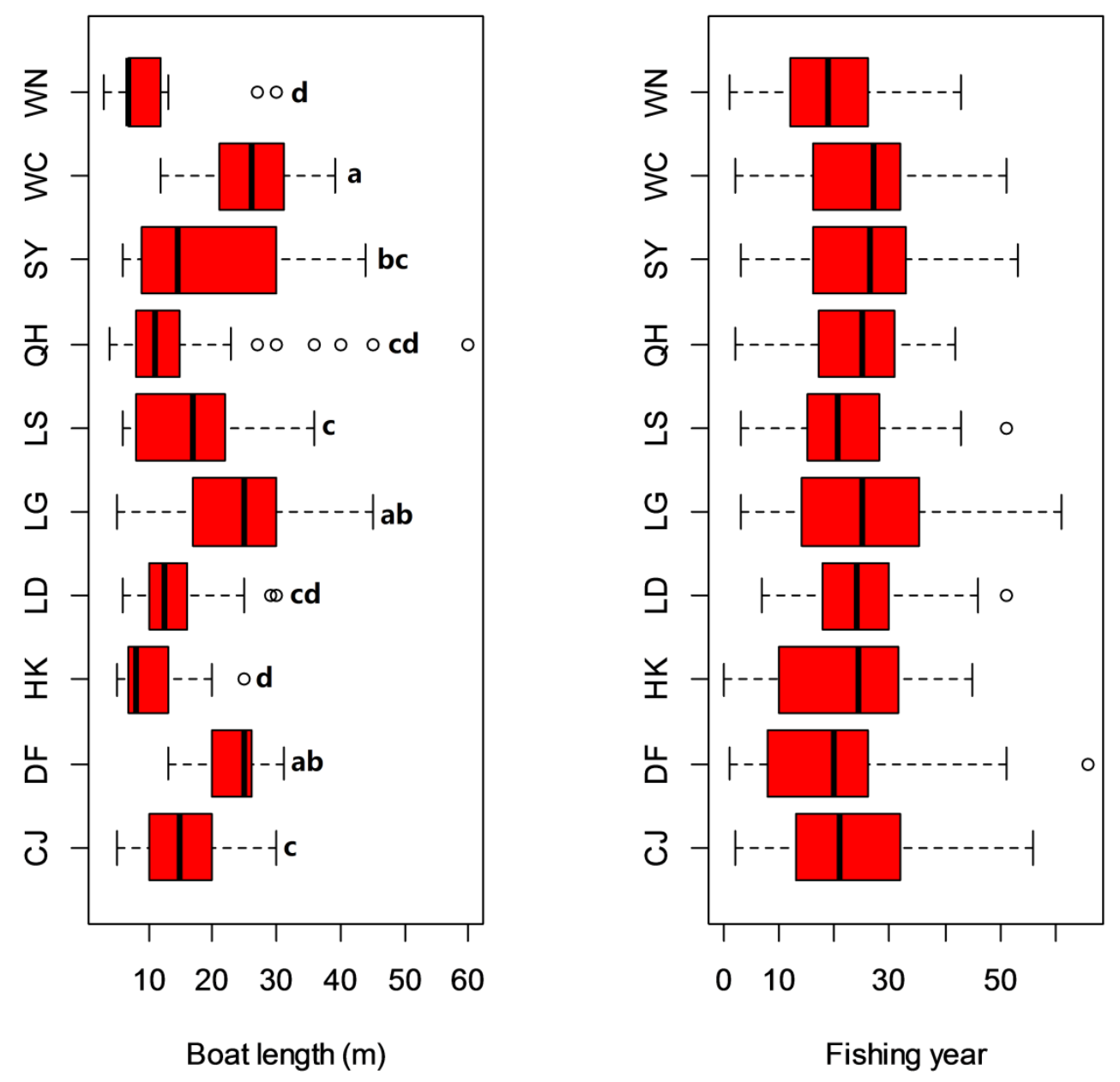

Fishing year

Fig. 2 

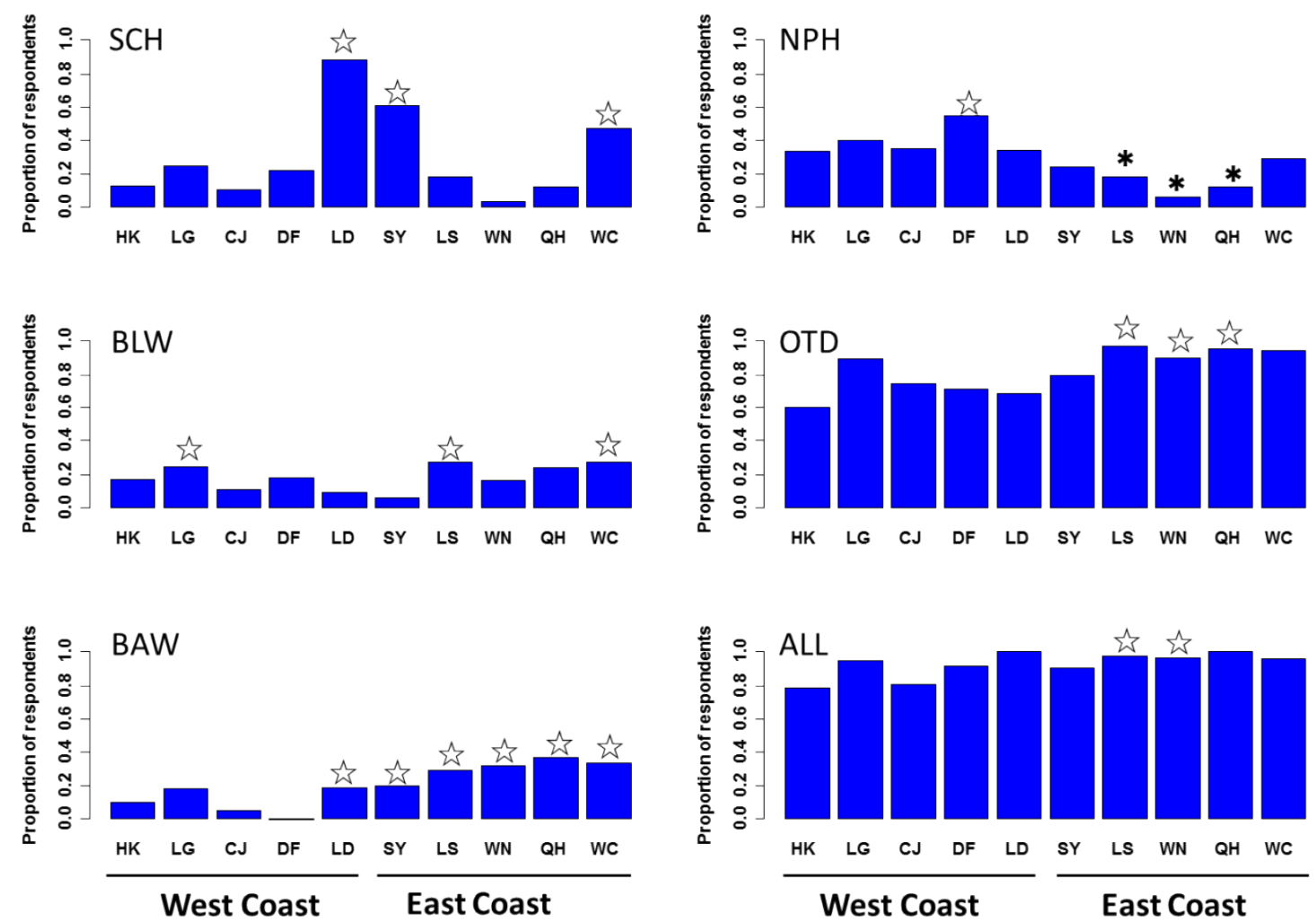

Fig. 3 


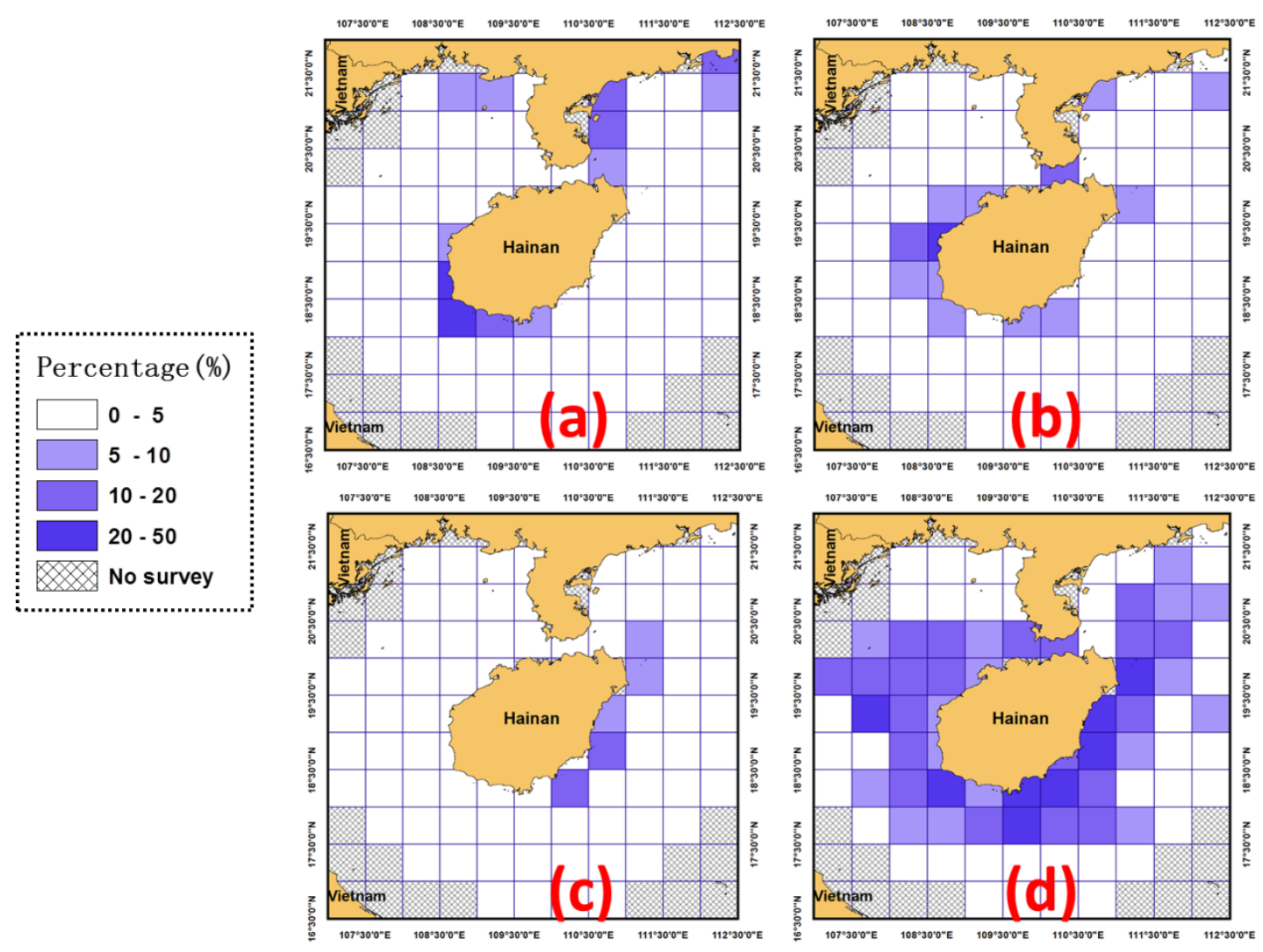

Fig. 4 

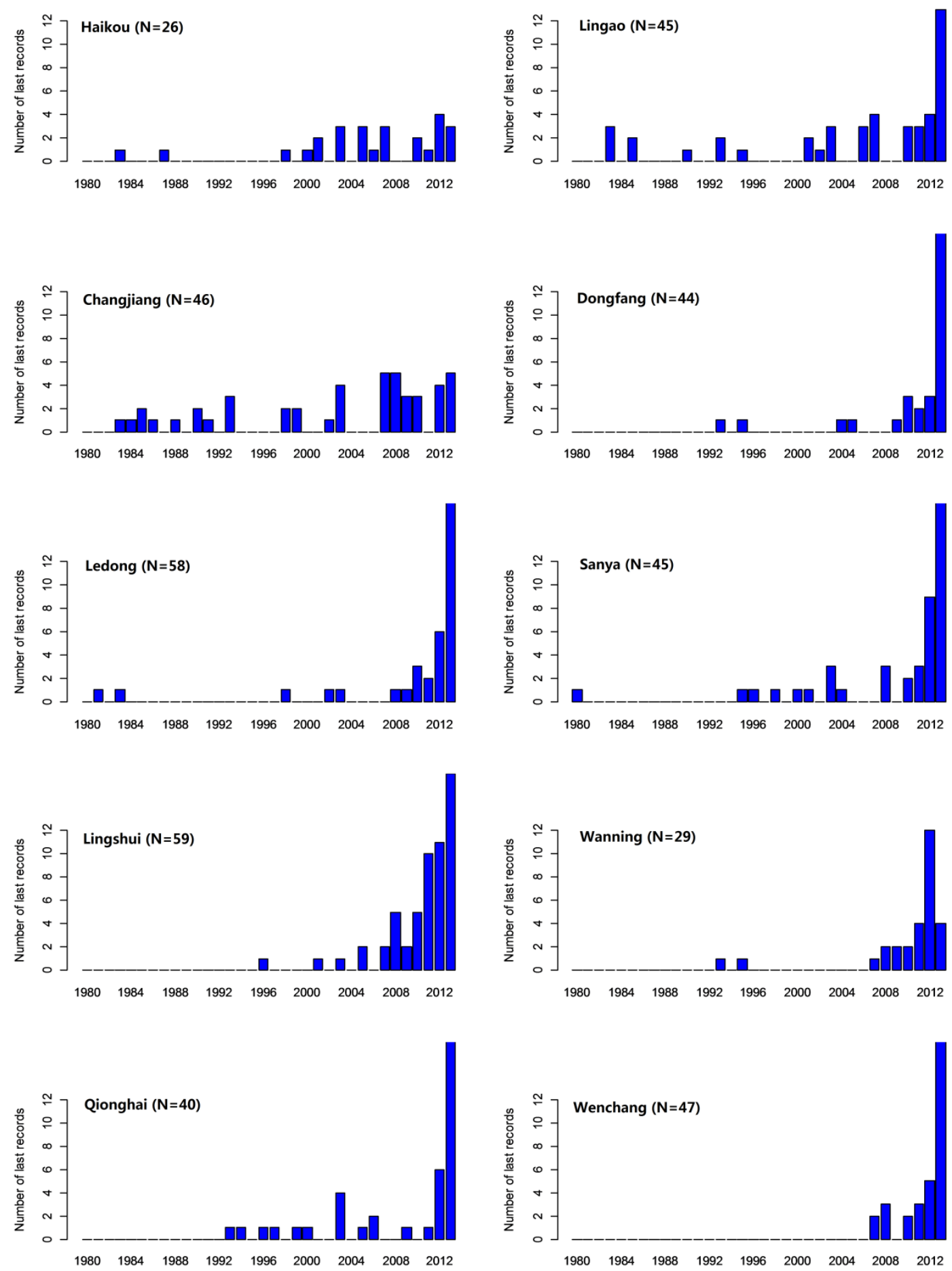

Fig. 5 

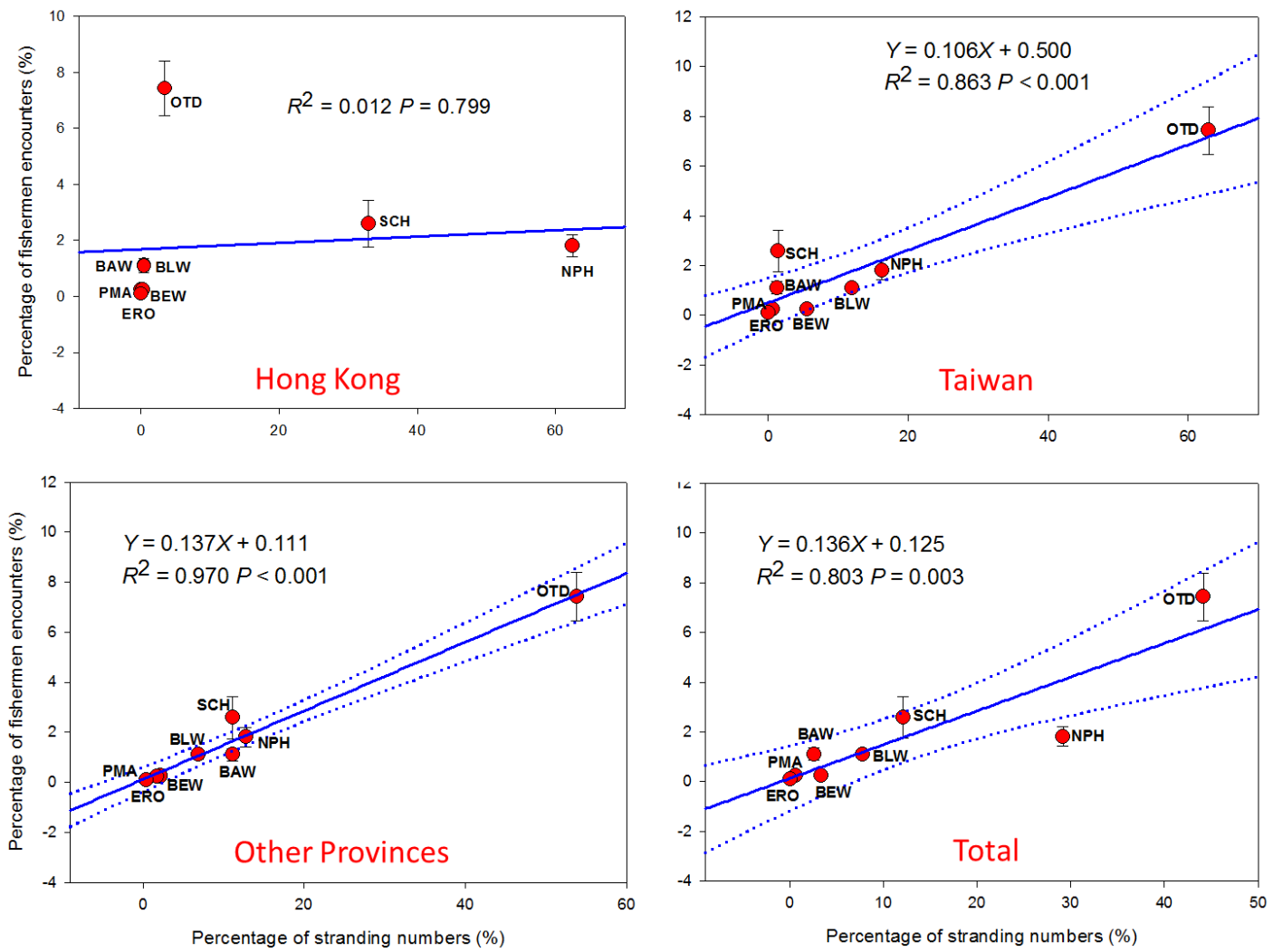

Fig. 6 


\section{Appendices A. Fishermen survey questionnaire (English version)}

DATE: LOCATION:

INTERVIEWER:

We undertaking an opinion survey related to fishers' local ecological knowledge on cetacean species. The outcome of the survey will be published in a peer-reviewed journal but will remain anonymous. Would you consent to participate in this study and answer questions related to this subject?

$\square$ Yes $\square$ No

\section{A: FISHERY AND CETACEANS}

1) How old are you?

Gender

Nationality

What is your education level?

$\square$ University/College $\square$ Senior mid school

Junior mid school $\square$ Elementary school

$\square$ Illiterate $\quad \square$ Other level (Please describe:

2) You have engaged in fishing from years old to years old

3) Which months do you fish at sea each year?

4) How long is your vessel?

5) Which fishing gears have you used recently?

1. Drift gillnets

$\square$ 2. Fixed gillnets

- 3. Trawls

4. Purse nets

$\square$ 5. Light-trapping

6. Electric-fishing 

7. Hooking
8. Long-line
9. Stow nets
10. Bomb-fishing

11. Other fishing gears or methods (Please describe:

6) Please identify your target fish species $(A-V)$ with the help of photographs of commercial fishes in the South China Sea; please list and describe if you mainly catch other species such as crustaceans or cephalopods.

A. Engraulis spp. (Anchoveta)

B. Pampus spp. (Butterfish)

C. Pagrosomus spp. (Sea bream)

D. Pseudosciaena spp. (Croaker)

E. Trichiurus spp. (Ribbonfish)

F. Etrumeus spp. (Herring)

G. Muraenesox spp. (Conger)

7. H. Argyrosomus spp. (White croaker)

_. I. Nibea ssp. (Yellow croaker)

J. Nemipterus spp. (Nemipterus)

K. Decapterus spp. (Scad)

L. Scombermorus spp. (Horse mackerel)

M. Thunnus spp. (Tuna)

N. Trachurus spp. (Mackerel)

O. Cynoglossidae spp. (Tonguefish)

_. P. Collichthys spp. (Croaker)

Q. Branchiostegus spp. (Tilefish)

R. Sardinella spp. (Sardine)

S. Mugil spp. (Mullet)

T. Navodon spp. (Filefish)

U. Epinephelus spp. (Grouper)

G V. Pneumatophorus spp. (Chub mackerel) 
$\square$ Other species (Please describe and list:

7) How many days do you devote to fishing on average every year?

8) Where do you typically engage in fishing?

(Please write down the grid numbers)

9) How have fishery resources changed during your fishing career?

a) Fishing catch

$\square$ Increase $\square$ Decrease $\square$ Unchanged

b) Number of fishing vessels
Increase
$\square$ Decrease
- Unchanged

10) Recent incidental catch of cetaceans:
a) Which fishing gears or methods?
b) Which species?
c) How many?
d) Where?
e) When?

11) If you have incidentally caught a cetacean, please describe its status:

$\square$ Dead $\square$ Alive but injured $\square$ Alive and not injured

Other status (Please describe:

12) Have you ever seen or heard that cetaceans were hit by propellers of fishing vessels?
$\square$ Ever seen
$\square$ Ever heard
$\square$ Never seen
$\square$ Never heard

If you have you ever seen or heard:
a) When did it happen?
b) Which species?
c) Where? (Please write down the grid numbers)

13) Relationship between fishing gears and cetaceans:

a) Which fishing gear is able to catch cetaceans most easily? 
b) How many cetaceans do you know this gear has caught?

c) Which other gears can also catch cetaceans?

B: DISTRIBUTION AND QUANTITY OF DOLPHINS (Adult length $<4 \mathrm{~m}$, typically without column of spray)

14) Please identify and list all dolphin species you have seen (Identify species with the help of the illustrated handbook, without any prompting or influence from colleagues present)

a) Which dolphin species have you seen most frequently?

b) Which dolphin species have you seen in the greatest numbers?

15) During which months is it easiest to see dolphins in your fishing area?

During which months is it more difficult to see dolphins in your fishing area?

16) Where do you see dolphins most frequently?

(Please write down the grid numbers)

17) About the largest size of dolphin group you have ever seen.

a) When?

b) Where? (Please write down the grid numbers)

18) How has the amount of dolphins changed during your fishing career?

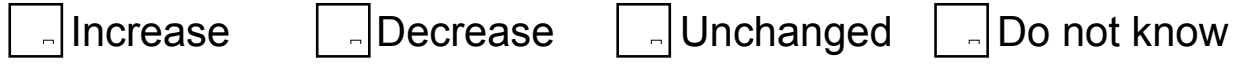

19) About your recent sighting(s) of stranded dolphin(s):
a) Which species?
b) How many?
c) When?
d) Where? (Please write down the grid numbers)

20) Have you ever seen Indo-Pacific humpback dolphins?

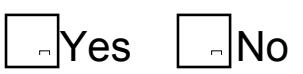
a) When?
b) Where? (Please write down the grid numbers)
c) How many?

21) Have you ever seen finless porpoises? 
$\square$ Yes $\square$ No

a) When?

b) Where?

c) How many?

(Please write down the grid numbers)

\section{C: DISTRIBUTION AND QUANTITY OF WHALES}

(Adult length $>4 \mathrm{~m}$, with recognizable spray column)

22) Please identify and list all whale species you have seen

(Identify species with the help of the illustrated handbook, without any prompting or influence from colleagues present)

23) Which whale species have you seen most frequently?

24) Describe recent sightings of whales at sea (not including stranded cetaceans):
a) Which species?
b) When?
c) Where?
(Please write down the grid numbers)

25) About the largest group size of whales you have ever seen?
a) Which species?
b) How many?
c) When?
c) Where? (Please write down the grid numbers)

26) Have you ever seen or heard of stranded whale(s):

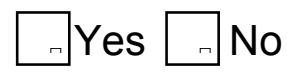
a) Which species?
b) How many?
c) When?
d) Where? (Please write down the grid numbers)

27) How has the number of whales changed during your fishing career?
- Increase
Decrease
$\square$ No change
Not sure

\section{D: PERCEPTIONS OF CETACEANS AND FISHERY}


28) Average family income per month:

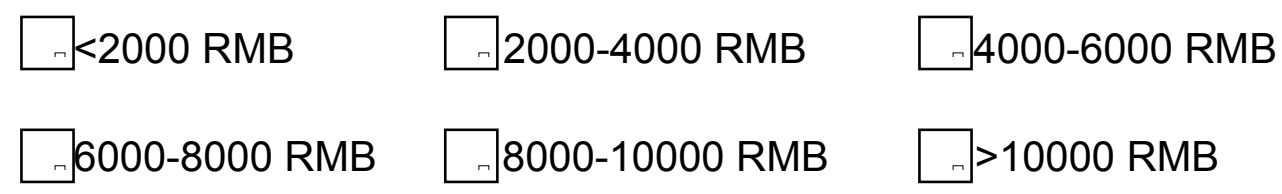

29) Do you think fishing is a good profession? $\square$ Yes $\square$ No

Do you hope that your children work as fishers?

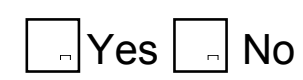

30) How often do you talk about cetaceans with other fishers?

$\square$ Frequently $\square$ Sometimes $\square$ Occasionally $\square$ Never

31) What topics do you discuss when you talk about cetaceans?

$\square$ Sighting cetaceans at sea $\quad \square$ Cetaceans hurt by vessels or nets

$\square$ Too many fish eaten by cetaceans $\square$ Stranding events

$\square$-ther topics (Describe:

32) Have you ever eaten dolphin or whale meat?

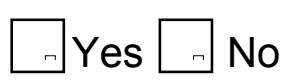

When have you recently eaten it?

33) Have you ever sold cetaceans? $\square$ Yes $\square$ No
a) $\square$ Dead $\square$ Alive
b) How much?
c) When?
d) Purposes of the buyer:

34) Do you think cetaceans play an important role in the marine ecosystem?

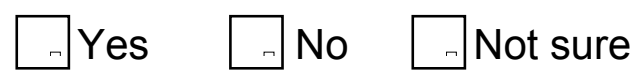

35) Do you think cetaceans should be protected?

$\square$ Yes $\square$ No $\square$ Not sure

36) Will fishery resources increase cetaceans are removed? 
$\square$ Yes $\square$ No $\square$ Not sure

37) Why have marine fishery resources decreased in your opinion?

$\square$ Increase of advanced fishing methods and gears

$\square$ Increased number of marine fishers

Fishery resources consumed by cetaceans

- Increasing water pollution

$\square$ Other reasons (Please describe:

38) Why have cetacean populations decreased?

$\square$ Reduction of food resources due to overfishing

- Increased collision risk from increasing vessel traffic

- Increased water pollution

$\square$ Other reasons (Please describe:

39) How do you deal with stranded cetaceans?

$G$ Free
S Sell
Eat

G Inform local fisheries administration $\square$ Ignore

TOther choices (Please describe:

40) How do you deal with entangled cetaceans?

$\square$ Free alive $\square$ Discard dead $\square$ Sell

$\square$ Inform local fisheries administration $\square$ Eat

GOther choices (Please describe: ___

41) Do you think cetaceans are national protected animals in China?

$\square$ Yes $\square$ No $\square$ Not sure 
42) Do you think that hunting or selling cetaceans is illegal?

$\square$ Yes $\square$ No $\square$ Not sure

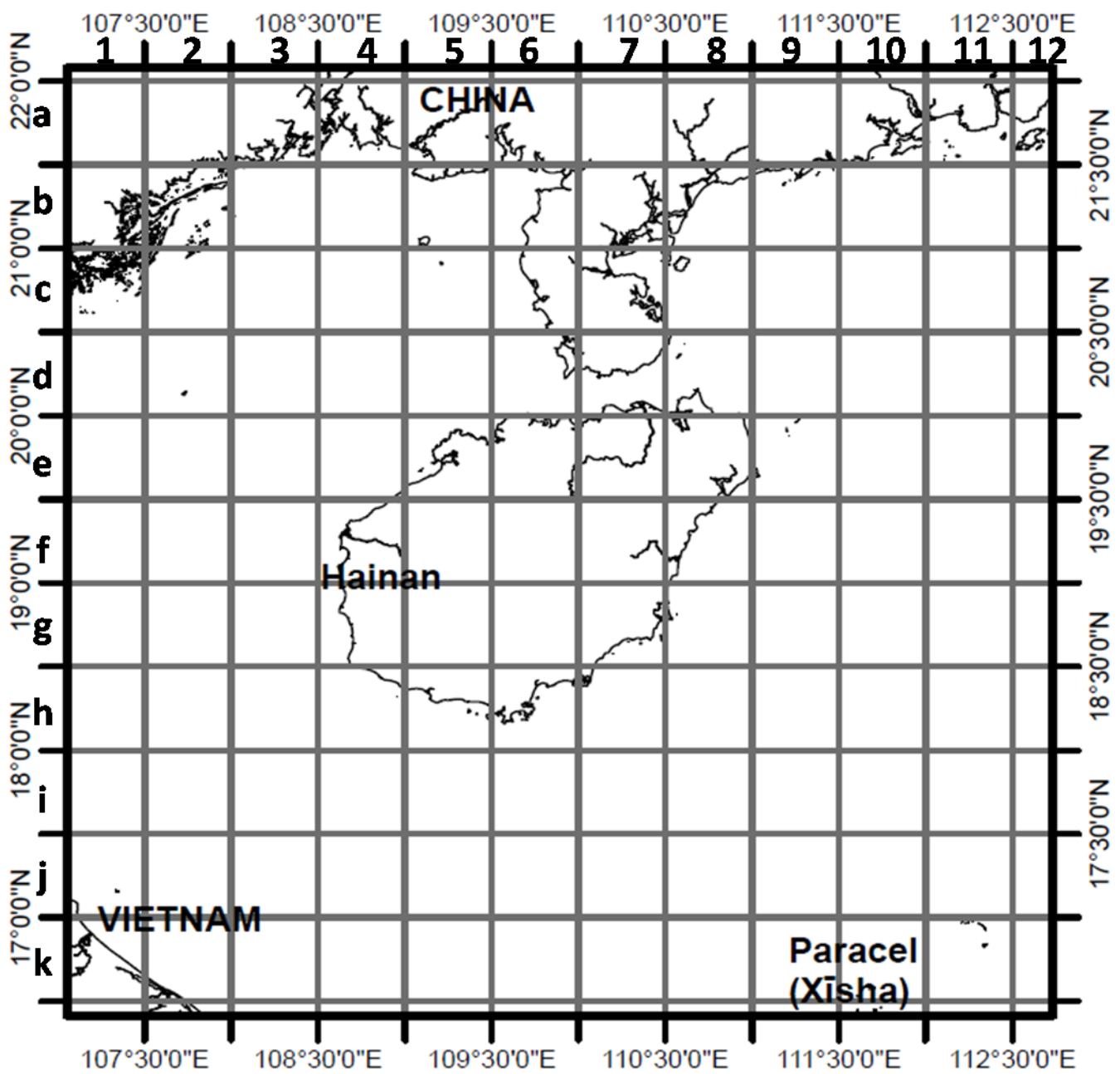

Figure S1 Grid map of Hainan and adjacent waters

1). Please write down grid numbers according to the format "Letter + Number" (e.g., b4).

2). Please record names or geographic locations on the map of other areas in the South China Sea that you have mentioned (e.g., Nansha, Xisha). 
